\title{
Hereditary progressive mucinous histiocytosis
}

INSERM

\section{Source}

INSERM. (1999). Orphanet: an online rare disease and orphan drug data base. Hereditary progressive mucinous histiocytosis. ORPHA:158025

Hereditary progressive mucinous histiocytosis is a rare, benign, non-Langerhans cell histiocytosis characterized by childhood or adolescence onset of multiple, small, asymptomatic, slowly progressing, skin-colored to red-brown papules with predilection for the face, dorsal hands, forearms and legs, without associated mucosal or visceral involvement. Histologically, papules are well-circumscribed, unencapsulated, nodular aggregates of histiocytes with abundant mucin in the upper and middermis. 